\title{
Forest species in ecological restoration of Cerrado vegetation
}

\section{Espécies florestais na restauração ecológica da vegetação do Cerrado}

\author{
Daniel Alves Vieira (10 ${ }^{1}$, Pedro Henrique Fernandes Silva² (D), Renan Augusto Miranda Matias ${ }^{1}$ (D), \\ Marco Bruno Xavier Valadão ${ }^{1}$ (D), Thalles Oliveira Martins ${ }^{1}$ (B), Fabiana Piontekowski Ribeiro ${ }^{1}$ (D), \\ José Roberto Rodrigues Pinto ${ }^{1}$ (D) Alcides Gatto ${ }^{1}$ (1) \\ 'Universidade de Brasília - UnB, Brasília, DF, Brasil \\ Universidade Federal de Goiás - UFG, Goiânia, GO, Brasil
}

\begin{abstract}
How to cite: Vieira, D. A., Silva, P. H. F., Matias, R. A. M., Valadão, M. B. X., Martins, T. O., Ribeiro, F. P., Pinto, J. R. R., \& Gatto, A. (2021). Forest species in ecological restoration of Cerrado vegetation. Scientia Forestalis, 49(132), e3519. https://doi.org/10.18671/scifor.v49n132.05
\end{abstract}

\begin{abstract}
The restoration of ecosystems in the Cerrado biome is challenging, and it is aggravated when colonization by invasive species occurs or when there was a degradation by mineral exploration. This study aimed to evaluate whether individuals from three fast-growing forest species - Peltophorum dubium (Spreng.) Taub., Lithraea molleoides (Vell.) Engl. and Terminalia argentea Mart. - had a fulfilling role of containing colonization by exotic species and the facilitating regeneration of woody species below tree canopies. Ten plots of $20 \mathrm{~m} \times 20 \mathrm{~m}$ were installed, measuring all individuals which had diameters at a height of 30 $\mathrm{cm}$ from the ground $(\mathrm{DHG})>5 \mathrm{~cm}$, total height $(\mathrm{TH})$, and canopy diameters (COPA). From the sampling of planted seedlings, three prominent species in DHG, TH and COPA and being abundant growing species in the study area were investigated as potential facilitators regarding abiotic characteristics (gravimetric humidity, luminosity, and resistance to penetration), which were measured in the areas under them. The studied species had a height increase considered high. In the case of the luminosity Peltophorum dubium presented greater canopy coverage than did Lithraea molleoides. For gravimetric moisture of the soil, Lithraea molleoides and Terminalia argentea presented the highest averages. Peltophorum dubium presented less soil penetration resistance at the depth of $20-40 \mathrm{~cm}$ and a greater number of regenerates in its direct influence area when compared to the other species. Overall, despite not having observed an increase in the number and richness of regeneration below the canopies, it is important that studies investigating the facilitation as a mechanism that promotes the agility to the restoration process in the Cerrado continue to be performed
\end{abstract}

Keywords: Positive interactions; Regeneration; Nucleation.

\begin{abstract}
Resumo
Restaurar ecossistemas do Bioma Cerrado é considerado um desafio, agravado quando ocorre colonização por espécies invasoras ou degradação pela exploração mineral. Esse trabalho teve o objetivo de avaliar se três espécies florestais de rápido crescimento - Peltophorum dubium, Lithraea molleoides e Terminalia argentea - estariam cumprindo o papel de conter a colonização por espécies exóticas e promover a facilitação da regeneração de espécies lenhosas abaixo de suas copas. Foram instaladas 10 parcelas de $20 \mathrm{~m} \times 20 \mathrm{~m}$, mensurando-se todos os indivíduos que apresentavam diâmetros à altura de $30 \mathrm{~cm}$ do solo (DAS) $\geq 5 \mathrm{~cm}$, altura total (HT) e diâmetros de copa (COPA). Da amostragem das mudas plantadas, três espécies de destaque em crescimento (DAS, HT e COPA) e abundantes na área de estudo foram investigadas como potenciais facilitadoras quanto as características abióticas (umidade gravimétrica, luminosidade e resistência à penetração) foram mensuradas nas áreas abaixo de suas copas, tendo essas características comparadas com clareiras. As espécies estudadas tiveram um
\end{abstract}

Financial support: None.

Conflict of interest: Nothing to declare.

Corresponding author: fbn2.ribeiro@gmail.com

Received: 19 November 2019.

Accepted: 6 May 2021.

Editor: Paulo Henrique Müller Silva. (c) T) This is an Open Access article distributed under the terms of the Creative Commons Attribution License, which permits unrestricted use,
gy distribution, and reproduction in any medium, provided the original work is properly cited. 
aumento de altura considerado alto. No caso da luminosidade, Peltophorum dubium apresentou maior cobertura do dossel em relação a Lithraea molleoides. Para a umidade gravimétrica do solo, Lithraea molleoides e Terminalia argentea apresentaram as maiores médias. Peltophorum dubium apresentou menor resistência do solo à penetração de $20-40 \mathrm{~cm}$ de profundidade e maior número de regenerantes em sua área de influência direta em comparação às demais espécies. No geral, apesar de não ter sido constatado o aumento do número e riqueza de regenerantes abaixo de suas copas, é importante que estudos que investiguem a facilitação como um mecanismo que acelera o processo de restauração no Cerrado continuem sendo realizados.

Palavras-chave: Interações positivas; Regeneração; Nucleação.

\section{INTRODUCTION}

The conversion of natural ecosystems such as the Cerrado for other uses, like the expansion of the agricultural frontier, mainly aimed at forming pastures for an extensive system of animal husbandry and grain cultivation, has led to the degradation of environments over the years. It is estimated that Brazil has around 140 million hectares of degraded areas, equivalent to $16.5 \%$ of the national territory (Instituto Brasileiro de Geografia e Estatística, 2012; Empresa Brasileira de Pesquisa Agropecuária, 2016). These degraded areas are due to the loss of soil quality; in particular fertility, or were compacted due to intense use, animal trampling or agricultural machinery.

Efforts in restoration ecology have sought to establish links between theories about the functioning of ecosystems and the applicability of these theories to practice (Perring et al., 2015; Aronson et al., 2018; Bucharova et al., 2019). Among the most important processes involved in community formation, facilitation can be highlighted (Melo et al., 2015). The majority of empirical studies reporting facilitative interactions do so in harsh environments, leading to hypotheses that the frequency of these interactions tends to vary according to the gradients in environmental conditions (Soliveres et al., 2014).

Therefore, facilitation has an application potential in the restoration of areas, which due to condition of intense degradation present problems related to natural regeneration establishment (Gomez-Aparicio et al., 2004). However, despite its potential, facilitation has been a poorly studied process for its application in restoration activities (Melo et al., 2015; Bizuti et al., 2016).

Faced with the growing demand for strategies to render the restoration of tropical ecosystems ecologically and economically viable, discussions have centered around the potential of using natural processes in assembling communities as a way of optimizing the results of restorative actions (Corbin \& Holl, 2012; Zahawi et al., 2013; Yelenik et al., 2015; Galindo et al., 2017)

Restoration strategies adopted in tropical forests can be an effective measure; including natural regeneration, assisted natural regeneration (firebreaks, weed control, erosion control and topsoil replacement), enrichment planting (planting of seedlings grown in nurseries and from direct sowing), commercial restoration (forest plantations and agroforestry systems) and control of climatic conditions for seedlings (Schlaepfer et al., 2014; Scheper et al., 2021).

There are reports of species that are capable to better trigger this process, for example Peltophorum dubium (Spreng.) Taub. (Fabaceae) is described as a long-lived species but with some pioneer characteristics, such as being light tolerant, rustic and fast growing; and it is widely used in restoration plantations in Brazil due its high levels of field survival, growth and biomass accumulation. This species is also mentioned as being capable of favoring shade tolerant species development (Bertolini et al., 2015).

Terminalia argentea Mart. (Combretaceae) is a pioneer and light tolerant, deciduous, and of preferential occurrence in well drained and dry soils. It produces large quantities of viable seeds (Otsubo et al., 2015). Lithraea molleoides (Vell.) Engl. (Anacardiaceae) is also a pioneer and light tolerant (Lorenzi, 2008), with perennial leaves. Its dispersion is done by animals, and Ferreira et al. (2009) pointed out that through its natural regeneration it can easily colonize disturbed areas. 
Therefore, can the species Peltophorum dubium, Terminalia argentea and Litharea molleoides be facilitators in the restoration process in an area that has been used for the cultivation of sugar cane for more than 10 years? To answer this question, the following hypotheses were tested: (I). These species are capable of achieving high growth in the process of restoration. (II). They present modifications in abiotic characteristics in the micro-habitat below their crowns. (III). These modifications provide less ground cover for exotic grasses and allow for a higher density and richness of regenerating woody species in the micro-habitats below their crowns.

Therefore in an area altered by agricultural use and subsequently submitted to a restoration model, this study aimed to evaluate, whether individuals of these three species would be fulfilling the role of containing colonization by exotic species (especially those of the genus Urochloa sp., abundant in the study area) and to promote Cerrado woody species regeneration below their canopies.

\section{MATERIAL AND METHODS}

\section{Study Area}

The study area consists of a restoration planting located in Paracatu (Figure 1), a

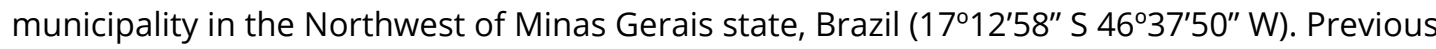
to restoration planting, the area was used for a sugarcane crop for more than 10 years and currently it is bordered by a sugarcane plantation irrigated by a central pivot.
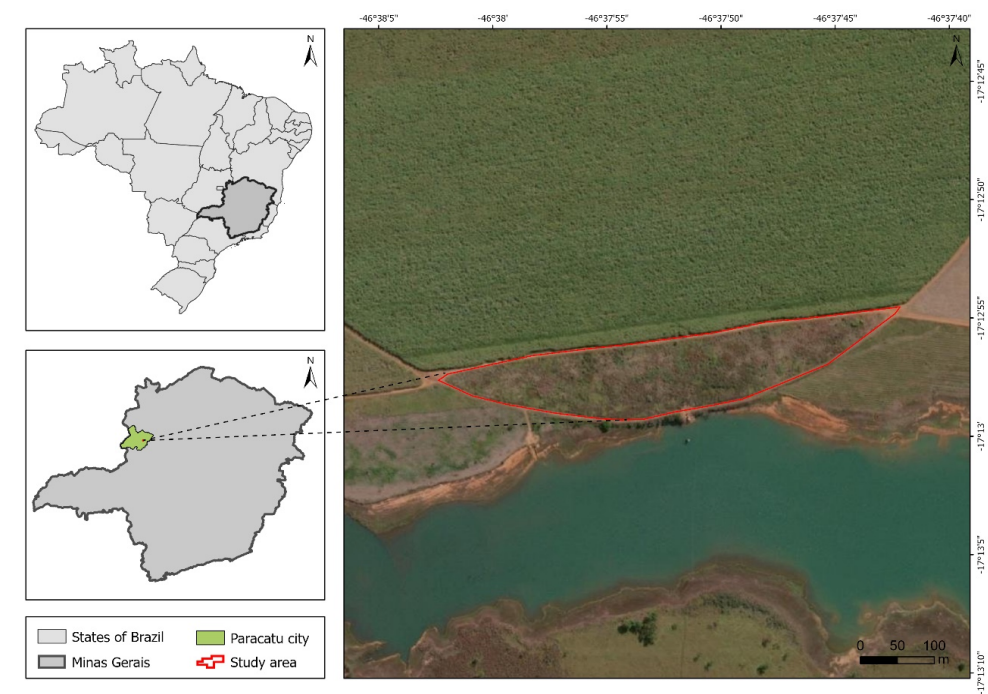

Figure 1. Map of study area in Paracatu, Minas Gerais state, Brazil.

According to the classification system of Köppen, the region's climate is Aw, with dry winter (Alvares et al., 2014). Climatic periods are well defined: the rainy season is concentrated from October to March, and the dry season from April to September, with an average annual precipitation of $1,314 \mathrm{~mm}$. Average annual temperature is $23^{\circ} \mathrm{C}$, the mean of the coldest month is $16.5^{\circ} \mathrm{C}$ and of the hottest month is $29.5^{\circ} \mathrm{C}$ (Instituto Nacional de Meteorologia, 2017). The soil was described as being "Latossolo Vermelho" (Empresa Brasileira de Pesquisa Agropecuária, 2018) and the relief varies from flat to soft wavy (Marques et al., 2012).

\section{Data collection}

Restoration planting occurred in December 2010, conducted in lines where 5,513 seedlings of 36 native Cerrado tree species were planted in circular pits with dimensions of $30 \mathrm{~cm} \times 60 \mathrm{~cm}$ (diameter $\times$ depth), $3 \mathrm{~m} \times 3 \mathrm{~m}$ spacing and the total plating area was of $5.32 \mathrm{ha}$. 
Liming was carried out before fertilization and in each pit $100 \mathrm{~g}$ of NPK (4-30-16) and $1.0 \mathrm{~kg}$ of tanned cattle manure was applied.

The study was performed five years after restoration planting, with the selection of ten trees of each of the Cerrado forest species (Lithraea molleoides, Terminalia argentea and Peltophorum dubium) selected randomly in the study area, and diameters at ground height (DHG), total height (TH) and canopy diameter (COPA) measured.

Circular plots of $10 \mathrm{~m}^{2}$ were marked around the selected individuals of these three species, considering each individual as a central point and a radius of $3.57 \mathrm{~m}$. Thus, the interior of the plots was considered as an area of direct influence of the facilitating trees, similar to the methods performed by Passos et al. (2014) and Melo et al. (2015). Furthermore ten circular plots of $10 \mathrm{~m}^{2}$ were demarcated on clearings - i.e. areas with without vegetation cover, generated by the death of planted seedlings, distributed throughout the study area.

Soil cover by exotic grasses in these areas was estimated within metal frames with dimensions of $50 \times 50 \mathrm{~cm}$, subdivided in its interior by 25 squares of $10 \mathrm{~cm} \times 10 \mathrm{~cm}$; with the percentage of coverage recorded by the number of quadrants filled with exotic grasses divided by the total number of quadrants. In addition, the number of individuals and richness of woody species regenerating in the plots was recorded, similarly to the methods performed by Alvino-Rayol et al. (2011).

Abiotic variables were evaluated in order to verify if environmental factors could be associated with differences in soil cover areas, such as: Gravimetric soil moisture (\%) estimated by samples composed of four single samples taken from the surface layer in circular plots; Soil penetration resistance - SRP (MPa) - estimated using an impact penetrometer, Stolf model, with three measurements in each circular plot up to $40 \mathrm{~cm}$ depth. The penetration resistance data were processed according to Stolf et al. (2014) for superficial $(0-20 \mathrm{~cm})$ and depth layers (20-40 cm); Luminosity (\%) - measured with of a luxmeter (Instrutherm, model LD 300) by means of four measurements taken at $1 \mathrm{~m}$ from tree trunk and at $1.30 \mathrm{~m}$ above the ground, following a methodology similar to that found in Melo et al. (2015). Luminosity measurements were performed on a cloudless day between $10 \mathrm{am}$ and $1 \mathrm{pm}$.

\section{Data analysis}

Parametric tests were performed to compare biotic and abiotic characteristics in the investigated areas. Parametric tests must meet the assumptions of normality of errors distribution and homogeneity of variances; we applied the Jarque-Bera test with 10,000 permutations and the Levene test respectively to the database. In order to meet these assumptions, values of the variables exotic grasses cover and luminosity expressed in percentages were transformed by applying the arcsin equation arcosene $(\sqrt{ } p / 100)$, as recommended by Zar (2010); and for soil gravimetric moisture the Box-Cox transformation was applied, as performed by Zanette et al. (2007). Subsequently, Analysis of Variance (ANOVA) was performed and when the null hypotheses of these analysis were rejected, differences in means were investigated by Tukey tests.

Due the fact that the variables number of individuals and species richness are counting values (discrete variables), which are not suitable for traditional parametric analyzes, descdist function of fitdistrplus package (Delignette-Muller et al., 2016) verified the data fit to the Poisson distribution. Thus, generalized linear models ( $g / m$ function) of the Poisson family and Tukey test (g/ht function of the multcomp package, Hothorn et al., 2016) were used to compare these variables in areas.

Environmental variables' effects on soil cover by grasses, as well as in the number and richness of regenerating woody individuals was verified with the mixed generalized linear models (GLMM), using the g/mer function of the mImRev package (Bates et al., 2014).

In order to verify if the generated models presented an over-dispersion, the dispersion_glmer function of the b/meco package was used (Korner-Nievergelt, 2015). The Spearman correlation coefficients were estimated for variables that showed significant effects in the models through the cor function. The R software, version 3.3.2 was used for data analysis, adopting as significance level $\alpha \leq 0.05$. 


\section{RESULTS}

Dendrometric characteristics such as DHG, TH and COPA for each species were described at Table 1. The highest values were observed for Peltophorum dubium, while the species Terminalia argentea and Lithraea molleoides showed similar DHG and TH values.

Table 1. Dendrometric characteristics of the evaluated species in the study area.

\begin{tabular}{cccc}
\hline Species & DHG $(\mathbf{c m})$ & TH $(\mathbf{m})$ & COPA $(\mathbf{m})$ \\
\hline Peltophorum dubium (Spreng.) Taub. & $17.47 \pm 0.95$ & $6.8 \pm 0.7$ & $7.3 \pm 0.8$ \\
Terminalia argentea Mart. & $11.22 \pm 0.73$ & $6.0 \pm 0.5$ & $3.5 \pm 0.4$ \\
Lithraea molleoides (Vell.) Engl. & $11.20 \pm 0.58$ & $5.9 \pm 0.6$ & $5.1 \pm 0.7$ \\
\hline
\end{tabular}

DHG = Diameter at a height of $30 \mathrm{~cm}$ from the ground $(\mathrm{cm}) ; \mathrm{TH}=$ Total height $(\mathrm{m}) ; \mathrm{COPA}=$ crown diameter $(\mathrm{m})$

The variable related to the interception of solar radiation showed a significant difference between treatments $(F=3.967 ; p<0.05)$, but a significant difference was verified through the Tukey test only between areas with vegetation cover when compared to clearing areas; that is, the interception of solar radiation does not differ between the analyzed tree species. The clearings' was the one with highest solar radiation (100\% light), followed by areas below canopies of $P$. dubium (13.7\%) and T. argentea $(10.09 \%)$, while the lowest value occurred below the canopies of L. molleoides (4.1\%) (Figure $2 \mathrm{~A}$ ).

The lowest mean value of soil moisture was found below the canopies of $P$. dubium, with the lowest mean value of gravimetric moisture (13.72\%), significantly lower than those of the other treatments $(F=7.05 ; p<0.01)$. Lower mean values of moisture in the clearings $(15.23 \%)$ than the other areas were expected due to higher solar radiation incidence, which promotes temperature increase and consequently greater water evaporation and higher transpiration rates. However, there was no statistically significant difference in relation to those soil gravimetric moistures found in areas below the canopies of L. molleoides (15.59\%) and T. argentea (15.61\%) (Figure 2B).

Regarding the values of soil penetration resistance, in the $0-20 \mathrm{~cm}$ layer there were no significant differences between the four areas investigated, with mean values varying between $11 \mathrm{MPa}$ and $13.2 \mathrm{MPa}$. However, in the $20-40 \mathrm{~cm}$ layer there were significant differences between areas $(\mathrm{F}=14.33 ; p<0.01)$, with higher resistance in L. molleoides and T. argentea (13.9 and 15.2 $\mathrm{MPa}$, respectively). Although moisture content in the area of $P$. dubium was lower than in the others, it presented the lowest mean for this variable in the 20-40 cm layer (10.71 MPa), but no significantly difference between the mean observed in the clearings (11.26 MPa) (Figure 2C).
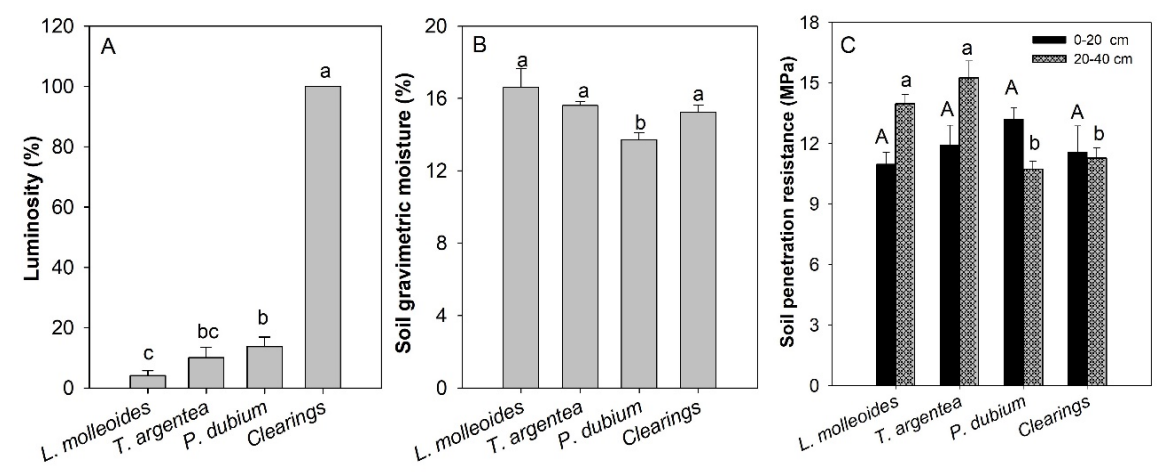

Figure 2. Abiotic variables investigated in the areas under the canopy of planted native species and in clearings in the study area. (A) luminosity; (B) soil gravimetric moisture; (C) Soil penetration resistance on superficial and subsurface layers. Same letters do not differ by Tukey test, $p<5 \%$, bars represent the standard error. Uppercase letters refer to $0-20 \mathrm{~cm}$ and lowercase letters refer to $20-40 \mathrm{~cm}$ of depth. 
Soil cover by exotic grasses in clearings was relatively high (83.2\%). Values found in areas below canopies of the three species investigated were lower, and considering only the three species, no statistically differences were observed $(10.7 \%, 22.9 \%$ and $13.2 \%$ below L. molleoides, $T$. argentea and $P$. dubium, respectively), but presenting significantly lower means when compared to clearings' soil cover $(F=23.53 ; p<0.01)$ (Figure 3A).

A total of 134 woody individuals regenerating in the 40 circular plots of the study of facilitation were counted, most of them classified as subshrub species (woody base and herbaceous apex) or shrub (woody plants branching from the base) (Richards, 1996), with few tree species. In clearings (about four individuals per clearing) and below P. dubium canopies (about seven individuals), mean values for number of regenerating individuals were significantly higher than below canopies of $T$. argentea (close to two individuals) and of L. molleoides (about one individual). Regarding species richness, there were no significant differences between the four areas, with this parameter ranging from about one species (below the canopies of L. molleoides) to two species (below the canopies of $P$. dubium) (Figure 3B).
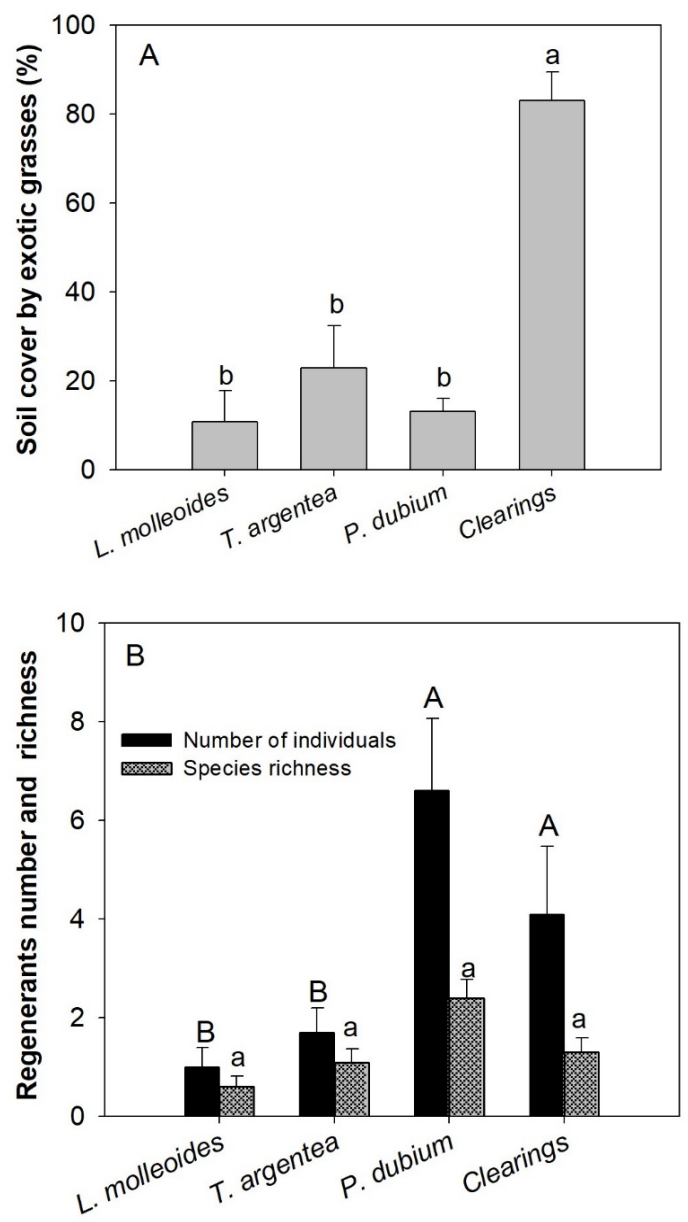

Figure 3. Biotic variables investigated in the areas under the canopy of planted native species and in clearings in the study area. (A) Soil cover by exotic grasses; (B) Number and species richness regenerating in the areas. Same letters do not differ by Tukey test, $p<5 \%$, bars represent the standard error. Uppercase letters refer to number of individuals and lowercase letters refer to species' richness.

With the aid of the generalized linear mixed models (GLMMs) it was verified that the variable luminosity was the only one to influence the exotic grasses' soil cover. Penetration resistance in the 20-40 cm layer (RP 20-40 cm) was the only variable with effect on woody individuals regenerating in the sample units. As for the richness of regenerating species, analyses did not show an effect of any of the variables investigated (Table 2). 
Table 2. Coefficients and significance ( $p$ value in parentheses) of the effects of predictive (abiotic) variables used in GLMMs for the response (biotic) variables.

\begin{tabular}{cccc}
\hline & \multicolumn{3}{c}{ Response variables } \\
\cline { 2 - 4 } Predictive variables & $\begin{array}{c}\text { Soil cover by exotic } \\
\text { grasses }\end{array}$ & $\begin{array}{c}\text { Number of } \\
\text { regenerants }\end{array}$ & Regenerants richness \\
\hline $\begin{array}{c}\text { Luminosity } \\
\text { Soil gravimetric moisture }\end{array}$ & $-0.0205(0.00)^{\star}$ & $0.0003(0.93)$ & $-0.0001(0.97)$ \\
$\begin{array}{c}\text { Soil penetration resistance } \\
(0-20 \mathrm{~cm})\end{array}$ & $-0.0052(0.83)$ & $-0.1215(0.42)$ & $-0.1487(0.22)$ \\
Soil penetration resistance & $0.0563(0.42)$ & $0.0559(0.36)$ \\
$(20-40 \mathrm{~cm})$ & $0.0712(0.18)$ & $-0.2501(0.00)^{\star}$ & $-0.0655(0.36)$ \\
\hline
\end{tabular}

$* p<0.01$.

Spearman correlation coefficient $\left(r^{2}\right)$ between cover exotic grasses' soil cover and solar radiation was equivalent to $-0.69(p<0.01)$. Among the number of woody individuals and RP 20-40 cm, $r^{2}$ was equivalent to $-0.58(p<0.01)$.

P. dubium and $T$. argentea presented similar results regarding light interception (Figure 2). However, a greater regenerator abundance in area below canopies of the former was found, leading to infer that the light factor is not the most important in this context. In addition, the results of the GLMM models (Table 2) indicated that light was not significant as a predictor of the density and richness of regenerating individuals. Similarly, the results regarding gravimetric moisture were also not significant as predictors.

\section{DISCUSSION}

The high values of the dendrometric characteristics shown by Lithraea molleoides, Terminalia argentea and Peltophorum dubium emphasize the capacity of these species to promote a facilitating environment for the regeneration process to take place. These species presented viability in natural regeneration after mining (e. g., L. molleoides) (Campos \& Martins, 2016), altered areas with soil loss and changes in soil chemistry and hydrology due to degradation (e.g., T. argentea) (Carvalho, et al., 2020) and in degraded riparian forest (Meli et al., 2018) or water-logged soil (Carvalho, et al., 2016) (e.g., P. dubium).

Previous knowledge of species' performance can guarantee good results; considering the characteristic of the Cerrado formation to be implemented in the restoration project. The coexistence of grasses, herbs, shrubs and trees leads to different growth forms and species diversity which might potentially create a complex native community (Pellizzaro et al., 2017).

This factor and the three species evaluated as potential facilitators were considered by the "Bioma Natives" model. Rapid growth promotes a soil cover which was previously dominated by exotic grasses; especially Urochloa sp. The integrated management of biological invasions should also be considered during the restoration process and permanent control programs need to be implemented to avoid a new invasion by exotic grasses (Assis et al., 2021).

Cerrado native species (e.g., Solanum lycocarpum A.St.-Hil., Anadenanthera colubrine, Croton floribundus Spreng., Inga laurina (Sw.) Willd., Inga vera Willd., Schinus terebinthifolia Raddi, and Syzygium cumini (L.) Skeels) were also reported to control exotic grasses (Passos et al., 2014). Some species are able to facilitate the establishment of a regeneration, presenting higher density and richness of woody individuals below their canopies when compared to clearings; but this pattern cannot be generalized for the entire biome. The fragmentation process in the Cerrado is correlated with the size of the area (Stefanes et al., 2018) and the soil parameters even at a different stage of regeneration (Pereira et al., 2021).

Some aspects (e.g., facilitating plants) have a positive effect on regenerating woody species' density and richness below their canopies. Pioneer Cerrado species (e.g., Cecropia pachystachya, Miconia elegans and Myrsine coriacea) are able to develop in secondary forest successions or to occupy the edges of forests or gallery forests in the Cerrado biome, and all of these produce a large number of fruits annually that is consumed by the avifauna 
(Oliveira et al., 2018). The higher deciduous canopies of certain trees also allow for optimal amounts of light penetration, benefiting an abundance of regenerating species and their diversity (Melo et al., 2015).

Among the abiotic factors that could act as facilitating factors, only the soil penetration resistance in the $20-40 \mathrm{~cm}$ layer was associated with effects on the regenerates' number after six years. After one decade, even in the passive restoration process, the vegetation cover promoted the reduction of SRP from $20 \mathrm{~cm}$ soil layer downwards in the Cerrado soil (Pereira et al., 2021). Thus, reduction of soil compaction favors the occurrence of a greater number of individuals regenerating. Several studies have emphasized the importance of estimating compaction in evaluating the factors that may be influencing the establishment of native regenerating species in restoration actions (Simmers \& Galatowitsch 2010; Passos et al., 2014; Yelenik et al., 2015).

Latosols with clayey texture are susceptible to compaction, and this process is common in soils cultivated with sugarcane, due to the frequent traffic of heavy machinery and the promotion of a decreased soil physical quality (Silva \& Castro, 2014; Cherubin et al., 2016). Another probable cause of compaction is the fact that the area is located in the lower part of a topological sequence, where transport and natural sedimentation of clays and lower moisture also influence the soil resistance to penetration (Reichert et al., 2007).

Although there is no consensus of critical compaction limits for plant growth, the penetration resistance values reported in the literature for agricultural crops are generally between 2.0 and 2.5 MPa (Reichert et al., 2007; Lima et al., 2014), with means found four to six times larger than these limits. Tree species are expected to support upper limits, but with restriction of growth.

In this context, $P$. dubium stands out among the species studied as potential facilitators, since it presented better growth and lower values of soil penetration resistance in the subsurface layer below its canopies (i.e., SRP 20-40 $\mathrm{cm}=10.71 \mathrm{MPa}$ ). This SRP value is high compared to annual crops, pasture and even sugarcane in deeper Cerrado Oxisol layers (Costa et al., 2020).

Even after ten years of sugarcane cultivation there is still a negative effect on the soil physical properties of the area. Carpanezzi \& Carpanezzi (2006) pointed out that the sugar cane has adaptations to shallow or stony soils, where conditions limiting root growth are expected. Minor SRP $(20-40 \mathrm{~cm})$ in areas planted to this species may be a reflection of subsoil changes due to rapid tree growth, just as the subsoil of clearings seems to be affected by abundant exotic grasses due to the lower SRP $(20-40 \mathrm{~cm})$ found in these areas as well.

Although some results indicated that exotic grasses provided some mitigation in soil compaction conditions in the $20-40 \mathrm{~cm}$ layer, the use of this type of vegetation in restoration programs is not a viable option according to several studies, due to their aggressive dispersion and colonization capacities, which may harm native species; as well as for producing fuel which render it very susceptible to fires in the dry season (Modna et al., 2010; Neri et al., 2011).

In the present study area, agricultural use for a long period of time turned the seed bank of species with an arboreal habit inexpressive. The short time of the restoration process also showed a delay in the restoring properties to be considered ideal. In addition there is the fact that not all planted species reached the maturity and fruit production phase, minimizing the seed fall coming from the planted vegetation itself, which could potentiate the regeneration and show more clearly the effects of the facilitation in the study area.

\section{CONCLUSIONS}

Shading promoted by potential facilitating species was sufficient to control grass establishment below their canopies, fulfilling the premise of containing colonization by exotic species.

Peltophorum dubium stood out among the other studied species, due to its growth in canopy diameter, which can trigger the facilitation processes, given the greater number of 
regenerating individuals close to this species and the reduced degree of compaction in the subsurface layer $(20-40 \mathrm{~cm})$ from the ground.

Despite the greater number of regenerating individuals close to the individuals of Peltophorum dubium, it is not possible to presently conclude that it acts as a facilitator in the process of natural regeneration, since it was of statistical equality when compared to the clearing areas.

\section{REFERENCES}

Alvares, C. A., Stape, J. L., Sentelhas, P. C., Gonçalves, J. L. M., \& Sparovek, G. (2014). Köppen's climate classification map for Brazil. Meteorologische Zeitschrift, 22(6), 711-728. http://dx.doi.org/10.1127/0941-2948/2013/0507.

Alvino-Rayol, F. O., Rosa, L. S., \& Rayol, B. P. (2011). Efeito do espaçamento e do uso de leguminosas de cobertura no manejo de plantas invasoras em reflorestamento de Schizolobium amazonicum Huber Ex. Ducke (Paricá). Revista Árvore, 35(3), 391-399. http://dx.doi.org/10.1590/S010067622011000300003.

Aronson, J., Simberloff, D., Ricciardi, A., \& Goodwin, N. (2018). Restoration science does not need redefinition. Nature Ecology \& Evolution, 2(6), 916. http://dx.doi.org/10.1038/s41559-018-0536-0.

Assis, G. B., Pilon, N. A. L., Siqueira, M. F., \& Durigan, G. (2021). Effectiveness and costs of invasive species control using different techniques to restore cerrado grasslands. Restoration Ecology, 29(S1), 1-33. http://dx.doi.org/10.1111/rec.13219.

Bates, D., Maechler, M., \& Bolker, B. (2014). Package "mlmRev". Retrieved in 2014, April 13, from https://cran.r-project.org/web/packages/mlmRev/index.html

Bertolini, I. C., Debastiani, A. B., \& Brun, E. J. (2015). Caracterização silvicultural da canafístula (Peltophorum dubium (Sprengel) Taubert). Scientia Agrária Paranaensis, 14(2), 7-76. http://dx.doi.org/10.18188/1983-1471/sap.v14n2p67-76.

Bizuti, D. T. G., Taniwaki, R. H., Silva, R. J., Costa, C. O. R., Roncon, T. J., Viani, R., \& Brancalion, P. H. S. (2016). Influência da composição de espécies florestais no microclima de sub-bosque de plantios jovens de restauração. Scientia Forestalis, 44(112), 971-978. http://dx.doi.org/10.18671/scifor.v44n112.18.

Bucharova, A., Bossdorf, O., Hölzel, N., Kollmann, J., Prasse, R., \& Durka, W. (2019). Mix and match: regional admixture provenancing strikes a balance among different seed-sourcing strategies for ecological restoration. Conservation Genetics, 20(1), 7-17. http://dx.doi.org/10.1007/s10592-0181067-6.

Campos, W. H., \& Martins, S. V. (2016). Estrato de regeneração natural como indicador do processo de restauração em área de compensação ambiental pela mineração de calcário, município de barroso, MG, Brasil. Revista Árvore, 40(2), 189-196. http://dx.doi.org/10.1590/0100-67622016000200001.

Carpanezzi, A. A., \& Carpanezzi, O. T. B. (2006). Espécies nativas recomendadas para recuperação ambiental no estado do Paraná, em solos não degradados (57 p.). Colombo: Embrapa Florestas, 2006.

Carvalho, J. C. N., Silva, F. W. S., Leite, G. L. D., Azevedo, A. M., Teixeira, G. L., Soares, M. A., Zanuncio, J. C., \& Legaspi, J. C. (2020). Does fertilization with dehydrated sewage sludge affect Terminalia argentea (Combretaceae) and associated arthropods community in a degraded area? Scientific Reports, 10(1), 11811. http://dx.doi.org/10.1038/s41598-020-68747-z.

Carvalho, L. S. O., Lira, J. M. S., Rodrigues, A. C., Lara, T. S., Pacheco, F. V., \& Alvarenga, A. A. (2016). Resistance mechanisms of Peltophorum dubium (Sprengel) taubert submitted to flood conditions. Floresta e Ambiente, 23(4), 582-588. http://dx.doi.org/10.1590/2179-8087.135015.

Cherubin, M. R., Karlen, D. L., Franco, A. L. C., Tormena, C. A., Cerri, C. E. P., Davies, C. A., \& Cerri, C. C. (2016). Soil physical quality response to sugarcane expansion in Brazil. Geoderma, 267, 156-168. http://dx.doi.org/10.1016/j.geoderma.2016.01.004.

Corbin, J. D., \& Holl, K. D. (2012). Applied nucleation as a forest restoration strategy. Forest Ecology and Management, 265, 37-46. http://dx.doi.org/10.1016/j.foreco.2011.10.013.

Costa, R. X., Frazão, J. J., Machado, R. L., Pereira, D. R. M., Nascimento, L. M., Oliveira, A. P., \& Marques, V. S. (2020). Land-use changes the chemical and physical properties of an oxisol in the Brazilian Cerrado. The Journal of Agricultural Science, 12(9), 181-191. http://dx.doi.org/10.5539/jas.v12n9p181.

Delignette-Muller, M. L., Dutang, C., \& Pouillot, R. (2016). Package "fitdistrplus". Retrieved in 2016, April 13, from https://cran.r-project.org/web/packages/fitditrplus/index.html. 
Empresa Brasileira de Pesquisa Agropecuária - Embrapa. (2016). Programa fará mapeamento completo dos solos brasileiros. Brasília: Embrapa. Retrieved in 2021, March 31, from https://www.embrapa.br/busca-de-noticias/-/noticia/17550684/programa-fara-mapeamentocompleto-dos-solos-brasileiros

Empresa Brasileira de Pesquisa Agropecuária - Embrapa. (2018). Sistema brasileiro de classificação de solos (5. ed., 356 p.). Brasília: Embrapa.

Ferreira, W. C., Botelho, S. A., Davide, A. C., \& Faria, J. M. (2009). Estabelecimento de Mata Ciliar às margens do reservatório da Usina Hidrelétrica de Camargos, MG. Ciência Florestal, 19(1), 69-81. http://dx.doi.org/10.5902/19805098421.

Galindo, V., Calle, Z., Chará, J., \& Armbrecht, I. (2017). Facilitation by pioneer schrubs for the ecological restoration of riparian forest in the Central Andes of Colombia. Restoration Ecology, 25(5), 731-737. http://dx.doi.org/10.1111/rec.12490.

Gomez-Aparicio, L., Zamora, R., Gómez, J. M., Hódar, J. A., Castro, J., \& Baraza, E. (2004). Applying plant facilitation to forest restoration: a meta-analysis of the use of shrubs as nurse plants. Ecological Applications, 14(4), 1128-1138. http://dx.doi.org/10.1890/03-5084.

Hothorn, T., Bretz, F., Westfall, P., Heiberger, R. M., Schuetzenmeister, A., \& Scheibe, S. (2016). Package "multcomp". Retrieved in 2018, September 6, from https://cran.rproject.org/web/packages/multcomp/

Instituto Brasileiro de Geografia e Estatística - IBGE. (2012). Indicadores de desenvo/vimento sustentável (9. ed., 350 p.). Rio de Janeiro: IBGE.

Instituto Nacional de Meteorologia - INMET. (2017). Normais climatológicas. Retrieved in 2017, March 11, from http://www.inmet.gov.br/portal/index.php?r=clima/normaisClimatologicas

Korner-Nievergelt, F. (2015). Package "blmeco". Retrieved in 2015, September 11, from https://cran.rproject.org/web/packages/blmeco/index.html

Lima, R. P., Silva, A. R., \& Oliveira, D. M. S. (2014). Análise de trilha de atributos físicos na resistência à penetração de um latossolo amarelo. Revista de Agricultura Neotropical, 1(1), 65-74. http://dx.doi.org/10.32404/rean.v1i1.216.

Lorenzi, H. (2008). Árvores brasileiras: manual de identificação e cultivo de plantas arbóreas nativas do Brasil (5. ed.). São Paulo: Plantarum.

Marques, A. F. S. M., Martins Junior, P. P., Vasconcelos, V. V., \& Novaes, L. A. D. (2012). Proposição metodológica para a cartografia de solos e aptidão agrícola: estudo de caso para a bacia do Rio Paracatu. Revista Brasileira de Geografia Física, 1, 1-17. http://dx.doi.org/10.26848/rbgf.v5i1.232686.

Meli, P., Isernhagen, I., Brancalion, P. H. S., Isernhagen, E. C. C., Behling, M., \& Rodrigues, R. R. (2018). Optimizing seeding density of fast-growing native trees for restoring the Brazilian Atlantic Forest. Restoration Ecology, 26(2), 212-219. http://dx.doi.org/10.1111/rec.12567.

Melo, A. C. G., Daronco, C., Ré, D. S., \& Durigan, G. (2015). Atributos de espécies arbóreas e a facilitação da regeneração natural em plantio heterogêneo de mata ciliar. Scientia Forestalis, 43(106), 333-344.

Modna, D., Durigan, G., \& Vital, M. V. C. (2010). Pinus elliottii Engelm como facilitadora da regeneração natural da mata ciliar em região de Cerrado, Assis, SP, Brasil. Scientia Forestalis, 38(5), 73-83.

Neri, A. V., Soares, M. P., Meira Neto, J. A. A., \& Dias, L. E. (2011). Espécies de Cerrado com potencial para recuperação de áreas degradadas por mineração de ouro, Paracatu-MG. Revista Árvore, 35(4), 907918. http://dx.doi.org/10.1590/S0100-67622011000500016.

Oliveira, A. K. M., Bocchese, R. A., Pereira, K. R. F., \& Carvalho, T. D. (2018). Seed deposition by birds on artificial perches at different distances from a gallery forest in the Cerrado area. Floresta, 48(3), 363372. http://dx.doi.org/10.5380/rf.v48i3.55228.

Otsubo, H. C. B., Moraes, M. L. T., Moraes, M. A., José Neto, M., Freitas, M. L. M., Costa, R. B., Resende, M. D. V., \& Sebbenn, A. M. (2015). Variação genética para caracteres silviculturais em três espécies arbóreas da região do bolsão Sul-Mato-Grossense. Cerne, 21(4), 535-544. http://dx.doi.org/10.1590/01047760201521041317.

Passos, F. B., Mesquita Lopes, C., Gois Aquino, F., \& Ribeiro, J. F. (2014). Nurse plant effect of Solanum lycocarpum A. St.-Hil. in area of Brazilian Savanna undergoing a process of restoration. Brazilian Journal of Botany, 37(3), 251-259. http://dx.doi.org/10.1007/s40415-014-0079-9.

Pellizzaro, K. F., Cordeiro, A. O. O., Alves, M., Motta, C. P., Rezende, G. M., Silva, R. R. P., Ribeiro, J. F., Sampaio, A. B., Vieira, D. L. M., \& Schmidt, I. B. (2017). “Cerrado” restoration by direct seeding: field establishment and initial growth of 75 trees, shrubs and grass species. Revista Brasileira de Botanica. Brazilian Journal of Botany, 40(3), 681-693. http://dx.doi.org/10.1007/s40415-017-0371-6. 
Pereira, L. C., Balbinot, L., Matus, G. N., Dias, H. C. T., \& Tonello, K. C. (2021). Aspects of forest restoration and hydrology: linking passive restoration and soil-water recovery in Brazilian Cerrado. Journal of Forestry Research, 32, 1-11. http://dx.doi.org/10.1007/s11676-021-01301-3.

Perring, M. P., Standish, R. J., Price, J. N., Craig, M. D., Erickson, T. E., Ruthrof, K. X., Whiteley, A. S., Valentine, L. E., \& Hobbs, R. J. (2015). Advances in restoration ecology: rising to the challenges of the coming decades. Ecosphere, 6(8), 1-25. http://dx.doi.org/10.1890/ES15-00121.1.

Reichert, J. M., Suzuki, L. E. A. S., \& Reinert, D. J. (2007). Compactação do solo em sistemas agropecuários e florestais: Identificação, efeitos, limites críticos e mitigação. In C. A. Ceretta, A. L. S. Silva \& J. M. Reichert (Eds.), Tópicos em ciência do solo (pp. 49-139). Viçosa: Sociedade Brasileira de Ciência do Solo.

Richards, P. W. (1996). The tropical rain forest: an ecological study (450 p.). Cambridge: University Press.

Scheper, A. C., Verweij, P. A., \& van Kuijk, M. (2021). Post-fire forest restoration in the humid tropics: a synthesis of available strategies and knowledge gaps for effective restoration. The Science of the Total Environment, 771(1), 144647. http://dx.doi.org/10.1016/j.scitotenv.2020.144647.

Schlaepfer, D. R., Lauenroth, W. K., \& Bradford, J. B. (2014). Regeneration processes in big sagebrush (Artemisia tridentata). Rangeland Ecology and Management, 6(4), 344-357. http://dx.doi.org/10.2111/REM-D-13-00079.1.

Silva, A. A., \& Castro, S. S. (2014). Indicadores macro e micromorfológicos da qualidade física de um latossolo vermelho textura média cultivado com Cana-de-açúcar na microrregião de Quirinópolis, Goiás. Boletim Goiano de Geografia, 34(2), 233-251. http://dx.doi.org/10.5216/bgg.v34i2.31731.

Simmers, S. M., \& Galatowitsch, S. M. (2010). Factors affecting revegetation of oil field access roads in semiarid grassland. Restoration Ecology, 18(1), 27-39. http://dx.doi.org/10.1111/j.1526100X.2010.00716.x.

Soliveres, S., Smit, C., \& Maestre, F. T. (2014). Moving forward on facilitation research: response to changing environments and effects on the diversity, functioning and evolution of plant communities. Biological Reviews of the Cambridge Philosophical Society, 90(1), 297-313. http://dx.doi.org/10.1111/brv.12110.

Stefanes, M., Roque, F. O., Lourival, R., Melo, I., Renaud, P. C., \& Quintero, J. M. O. (2018). Property size drives differences in forest code compliance in the Brazilian Cerrado. Land Use Policy, 75, 43-49. http://dx.doi.org/10.1016/j.landusepol.2018.03.022.

Stolf, R., Murakami, J. H., Brugnaro, C., Silva, L. G., Silva, L. C. F., \& Margarido, L. A. C. (2014). Penetrômetro de Impacto Stolf: programa computacional de dados em Excel-VBA. Revista Brasileira de Ciência do Solo, 38(3), 774-782. http://dx.doi.org/10.1590/S0100-06832014000300009.

Yelenik, S. G., Dimanno, N., \& D’antonio, C. M. (2015). Evaluating nurse plants for restoring native woody species to degraded subtropical woodlands. Ecology and Evolution, 5(2), 300-313. http://dx.doi.org/10.1002/ece3.1294.

Zahawi, R. A., Holl, K. D., Cole, R. J., \& Reid, J. L. (2013). Testing applied nucleation as a strategy to facilitate tropical forest recovery. Journal of Applied Ecology, 50(1), 88-96. http://dx.doi.org/10.1111/1365-2664.12014.

Zanette, S. V., Sampaio, S. C., Silvestre, M. G., Boas, M. A. V., Uribe-Opazo, M. A., \& Queiroz, M. M. F. (2007). Análise espacial da umidade do solo cultivado com soja sob dois sistemas de manejo. Revista Brasileira de Engenharia Agrícola e Ambiental, 11(3), 239-247. http://dx.doi.org/10.1590/S141543662007000300001.

Zar, J. H. (2010). Biostatistical analysis (944 p.). New Jersey: Prentice Hall.

Authors' contributions: AG and JRRP: conceptualization, funding acquisition, supervision; DAV, FPR, MBXV and RAMM: writing; DAV, PHFS and TOM: conceptualization, data curation, formal analysis, methodology; DAV, FPR, MBXV and RAMM: writing; DAV, FPR, PHFS, MBXV RAMM and TOM: data curation, formal analysis. 